\title{
NELL1 wt Allele
}

National Cancer Institute

\section{Source}

National Cancer Institute. NELL1 wt Allele. NCI Thesaurus. Code C128935.

Human NELL1 wild-type allele is located in the vicinity of $11 \mathrm{p} 15.1$ and is approximately $906 \mathrm{~kb}$ in length. This allele, which encodes protein kinase C-binding protein NELL1, plays a role in bone mineralization. 